Hegel's Dialectic 
This page intentionally left blank 


\section{Hans-Georg Gadamer}

\section{Hegel's Dialectic Five Hermeneutical Studies}

Translated and with an Introduction by P. Christopher Smith

New Haven and London Yale University Press 
Originally published in German under the title Hegels Dialektik, (1) 1971 by J. C. B. Mohr (Paul Siebeck), Tübingen.

Copyright 1976 by Yale University. All rights reserved.

This book may not be reproduced, in whole or in part, in any form (beyond that copying permitted by Sections 107 and 108 of the U.S. Copyright Law and except by reviewers for the public press), without written permission from the publishers.

Library of Congress catalog card number: 75-18171

International standard book numbers: 978-0-300-02842-3 